REVISTA DE DERECHO UNED, NÚM. 25, 2019

\title{
DIEGO DE SIMANCAS, JURISPERITO, CLÉRIGO Y PRETENDIENTE EN SU SIGLO XVI
}

\author{
DIEGO DE SIMANCAS, LAWYER, CLERIC AND CLAIMANT IN \\ HIS $16^{\mathrm{TH}}$ CENTURY
}

JuLián Gómez DE Maya

Universidad de Murcia

\begin{abstract}
Resumen: Diego de Simancas (1513-1583), catedrático en Valladolid, oidor en su Chancillería, inquisidor, obispo, autor de una obra esencialmente jurídica en la que sobresalen sus Instituciones católicas, de temática inquisitorial, dejó escrita también una curiosa autobiografía en la que, a partir de algunas consideraciones sobre la propia vocación, repasa aquellos y otros logros profesionales de su carrera, cuya trayectoria se corresponde o cabe identificar con cierto arquetipo de jurista propio de la Alta Edad Moderna, aquel que, formado en alguno de los colegios universitarios mayores, conjuga un ministerio eclesiástico con el desempeño de altos puestos en la vida pública civil: la cátedra universitaria y el canonicato, la oidoría y la coadjutoría archidiaconal, el Consejo Real y el báculo diocesano...
\end{abstract}

Palabras clave: Diego de Simancas, vocación jurídica, Colegios mayores, Consejos Reales, oficios públicos, Administración austracista.

Abstract: Diego de Simancas (1513-1583), was a Professor in Valladolid, magistrate in its Chancery, inquisitor, bishop and autor of a essentially legal work, in which his Catholic institutions, of inquisitorial theme, stands out. He also wrote a curious autobiography in which, after some considerations about his own vocation, he reviews those and other professional achievements of his career, whose trajectory corresponds or can be identified with certain ar- 
chetype of typical jurist of the High Modern Age, one that, formed in some Major University College, combines an ecclesiastical ministry with the performance of high positions in civil public life: the university chair and the canonicate, the court of justice and the dignity archdiaconal coadjutor, the Royal Council and the diocesan staff...

Key words: Diego de Simancas, legal vocation, Major University Colleges, Royal Councils, public offices, austracist Administration.

Recepción original: 29/04/2019

Aceptación original:7/11/2019

Sumario: I. Su formación. II. Pretensiones y profesiones. III. Defensa de los juristas: iurisperitos esse utilissimos. IV. Recapitulación.

"Fabio, las esperanzas cortesanas / prisiones son do el ambicioso muere / y donde al más activo nacen canas" ${ }^{1}$ : así abría el capitán Fernández de Andrada (1575-1648) la sublime Epístola moral a Fabio allá por los albores del siglo XVII. Muy pocos años antes, el también andaluz Diego -o bien Jacobo, Santiago- Bretón de Simancas (1513-1583), doctor in utroque iure, consejero de la Suprema Inquisición ${ }^{2}$ y de Estado ${ }^{3}$, sucesivamente obispo de Ciudad Rodrigo (1564-1568), de Badajoz (1568-1578) y de Zamora (1578-1583)4, corría desalado tras las esperanzas cortesanas y a fe que en su tiempo fue de los más activos e intelectualmente mejor dispuestos para ha-

${ }^{1}$ FERNÁNDEZ DE ANDRADA, Andrés, "Epístola moral a Fabio» y otros escritos, ed. Dámaso Alonso, Crítica, Barcelona, 1993, pág. 73 (vs. 1-3).

2 SÁNCHEZ RIVILLA, Teresa, "Inquisidores Generales y Consejeros de la Suprema: documentación biográfica", en Joaquín Pérez Villanueva y Bartolomé Escandell Bonet (dirs.), Historia de la Inquisición en España y América, Centro de Estudios Inquisitoriales, Madrid, 1984/2000, t. III, pág. 417. Agrega SOBALER SECO, María de los Ángeles, Catálogo de colegiales del Colegio Mayor de Santa Cruz de Valladolid (1484-1786), Universidad de Valladolid, Valladolid, 2000, pág. 174, su condición de consejero de Indias, desde el mismo año 1559 en que lo fue de la Suprema, pero se trata de un error (entre otras consideraciones, no figura en la nómina de SCHÄFER, Ernesto, El Consejo Real y Supremo de las Indias, Junta de Castilla y León y Marcial Pons, Salamanca, 2003, t. I, págs. 337-338).

3 BARRIOS, Feliciano, El Consejo de Estado de la Monarquía española, 15211812, Consejo de Estado, Madrid, 1984, págs. 332-333. Sin embargo, no aparece como tal en "El gobierno de la Monarquía: los consejeros de Felipe II", apéndice a José Martínez Millán y Carlos Javier de Carlos Morales (dirs.), Felipe II (1527-1598): la configuración de la Monarquía Hispana, Junta de Castilla y León, Salamanca, 1998, pág. 303, sino tan solo en cuanto consejero de la Inquisición (ibidem, págs. $306,482)$.

${ }^{4}$ ANTONIO, Nicolás, Bibliotheca hispana nova sive Hispanorum scriptorum qui ab anno MD ad MDCLXXXIV flourere notitia, Joaquín de Ibarra, Madrid, 1783/88, t. I, págs. 316-317. 
cer carrera y "[...] subir al honor que pretendiere" ${ }^{5}$. Allende los datos y la cronología que la investigación archivística haya podido deparar, disponemos de un documento cardinal para inquirir el grado de correspondencia entre la vocación o las ambiciones del personaje y sus logros ciertos al correr de su existencia y ejercicio profesional; en efecto, escritas dejó Diego de Simancas La vida y cosas notables $^{6}$ suyas, juzgadas con unanimidad como apología dictada por la soberbia ${ }^{7}$, en expresión de Serrano y Sanz, de una vanidad casi pueril $^{8}$ - reprueba Domínguez Ortiz-, como monumento de egolatría intelectual $^{9}$, a juicio de Caro Baroja, o - en el concepto de Tellechea Idígoras - como alabanciosas memorias ${ }^{10}$, aunque asimismo tenidas por obra "[...] curiosa e interesante, con datos sobre la actividad política y profesional de un jurista del siglo XVI, sin paralelo en la bibliografía española de la época"11, según el profesor Bermejo Cabrero, que no vacila en tildar de espíritus pusilánimes a quienes la lectura de esta autobiografía inspira un claro rechazo hacia su personalidad histórica con inadvertencia de tantas posibilidades como para la historiografía entraña ${ }^{12}$. Bien se echa de ver que tanto aquellos reproches como este aprecio están certificando la utilidad del retrospectivo texto en orden a conocer o comprender, entre tantos otros particulares, el carácter, la índole temperamental de su autor en relación con los usos y expectativas profesionales del tiempo y estamento que le cupieron en suerte.

5 FERNÁNDEZ DE ANDRADA, «Epístola..., pág. 73 (v. 6).

6 SIMANCAS, Diego de, "La vida y cosas notables del señor obispo de Zamora don Diego de Simancas, natural de Córdoba, colegial del Colegio de Santa Cruz de Valladolid, escrita por el susodicho", en vv. aa., Autobiografías y memorias, colec. Manuel Serrano y Sanz, Bailly-Bailliére e Hijos, Madrid, 1905, págs. 151-210.

8 DOMÍNGUEZ ORTIZ, Antonio, Los judeoconversos en España y América, Itsmo, Madrid, 1971, pág. 86.

${ }^{9}$ CARO BAROJA, Julio, Las formas complejas de la vida religiosa (religión, sociedad y carácter en la España de los siglos XVI y XVII), Sarpe, Madrid, 1985, pág. 178.

10 TELLECHEA IDÍGORAS, José Ignacio, "Cartas inéditas de un inquisidor por oficio. El Dr. Simancas y el proceso romano de Carranza", en Antonio Carreira et al. (eds.), Homenaje a Julio Caro Baroja, Centro de Investigaciones Sociológicas, Madrid, 1978, pág. 966.

11 BERMEJO CABRERO, José Luis, "Apuntamientos sobre la vida y escritos de Diego de Simancas", en Salustiano de Dios et al. (coords.), El Derecho y los juristas en Salamanca (siglos XVI-XX). En memoria de Francisco Tomás y Valiente, Universidad de Salamanca, Salamanca, 2004, pág. 568.

12 BERMEJO CABRERO, “Apuntamientos...”, pág. 587. 


\section{SU FORMACIÓN}

Había nacido el año 1513 en Córdoba, de simanquino linaje por ambas ramas (era el padre juez de bienes del Santo Oficio en la metrópoli califal $)^{13}$, y le alcanzó la muerte en 1583, ordinario de la última diócesis que apacentara, la de Zamora. Si el mayor predicamento suyo le viene como tratadista del Santo Oficio ${ }^{14}$, su presencia en los libros de Historia dimana del protagonismo que llegó a ganar en la celebérrima causa fulminada contra el arzobispo de la sede toledana Bartolomé Carranza de Miranda (1503-1576), episodio al que también consagra holgada extensión de su autobiografía ${ }^{15}$. Pero vayamos por sus pasos contados, desde que riberas del Guadiana viera la primera luz:

[...] Estuve en aquella ciudad hasta que cumplí catorce años, en los cuales me mostraron á leer y escribir y gramática, y se conoció en mí habilidad para pasar adelante, y así, un día, tratándose de haber para mí un canonicato, dijo mi madre: Cargo de conciencia será no hacer que este niño estudie y sea un gran doctor; de la cual palabra nunca me olvidé y trabajé siempre por sacarla verdadera, á lo menos en ser doctor, como lo fuí en sus días ${ }^{16}$.

Mas, de repente, nos sorprende ya hecho todo examen de su ingenio: a lo que se nos muestra, sin mucho discernimiento ni caso de las doctrinas de su contemporáneo el fisiólogo navarro Juan Huarte de San Juan (1530-1592), precursoras de la psicología diferencial ${ }^{17}$.

13 Ciertas noticias familiares, en PÉREZ LOZANO, Manuel, y MORALEJO ORTEGA, Macarena María, "Don Diego de Simancas y la fundación de la capilla familiar en la Catedral-Mezquita de Córdoba", en María Dolores Barral Rivadulla et al. (coords.), Mirando a Clío: el arte español, espejo de su historia, Universidad de Santiago de Compostela, Santiago de Compostela, 2012, págs. 1502-1506.

14 Véanse, v. gr., AGUILERA BARCHET, Bruno, "El procedimiento de la Inquisición española", en Pérez Villanueva y Escandell Bonet (dirs.), Historia..., t. II, págs. 338-339; PÉREZ MARTÍN, Antonio, "La doctrina jurídica y el proceso inquisitorial”, en José Antonio Escudero (ed.), Perfiles jurídicos de la Inquisición española, Universidad Complutense de Madrid, Madrid, 1992, pág. 283; GACTO FERNÁNDEZ, Enrique, Estudios jurídicos sobre la Inquisición española, Dykinson, Madrid, 2012, passim.

15 SIMANCAS, "La vida...", págs. 156a-160a, 164a-185b. Amplíese en TELLECHEA IDÍGORAS, José Ignacio, "El proceso del arzobispo Carranza", en Pérez Villanueva y Escandell Bonet (dirs.), Historia...., t. I, págs. 556-598.

16 SIMANCAS, "La vida...", pág. 151a.

17 HUARTE DE SAN JUAN, Juan, Examen de ingenios para las ciencias, ed. Guillermo Serés, Cátedra, Madrid, 1989, págs. 149-156, 159-160, 393-422, etcétera. Compleméntese con MARAÑ́́N, Gregorio, Tiempo viejo y tiempo nuevo, EspasaCalpe, Madrid, 1940, págs. 124-135; IRIARTE, Mauricio de, El doctor Huarte de San Juan y su Examen de ingenios: contribución a la historia de la psicología diferencial, Consejo Superior de Investigaciones Científicas, Madrid, 1948, págs. 197-212; o MALLART, José, "Huarte y las modernas corrientes de ordenación profesional”, en Car- 
Se ha hablado en familia de haber un canonicato, de llegar a ser doctor, ahora - sin solución de continuidad, pero a la par sin nexo ilativo- de estudiar Derechos..., rumbo hacia el cual endereza su itinerario académico, a cuyo término será tan solo cuando nos revele algo de sus íntimas aspiraciones profesionales.

[...] Y porque en Córdoba no había escuelas para estudiar Derechos, ni aun se mostraba bien Latinidad, me llevaron á Valladolid [...]; en Valladolid estudié un año más Latinidad, y con la afición que le tomé aproveché de manera que con un mediano estilo di algún lustre á todos mis actos públicos y mis escritos. Después comencé á oir Derechos en Valladolid, y á cabo de un año fuí á Salamanca, y allí estuve nueve años, oyendo á los Lectores cinco años y pasando cuatro, todo ello con mucho cuidado y provecho $[\ldots]^{18}$.

Curiosamente, entre las referencias noticiosas del escogimiento ocupacional, falta cualquier alusión a su presunta vocación religiosa, como no fuere ese tratándose de haber para mí un canonicato tan lejano de toda auténtica autognosis y de alguna tendencia o íntima disposición al ministerio, quizás porque, conforme denuncia el padre Mariana, si bien "no podemos pues admitir de ningun modo que se rechace de los cargos de la Iglesia á los jurisconsultos", demuestra a su entender la experiencia en cuán significativa proporción "son poquísimos los jurisconsultos que se ordenan sin que les mueva á ello algun pingüe beneficio, del que puedan vivir cómoda y esplendorosamente"19: permanezca el aserto o barrunto, respecto a Simancas, en el nivel de hipótesis por el momento...

De leyes fueron, pues, los estudios del cordobés, a quien tiene Caro Baroja por "[...] prototipo del jurista fiero, con ambición de ascender por vía eclesiástica a los más altos puestos de la vida pública civil"20; la secuencia resulta harto cursada y conocida, siendo así que "el joven letrado tiene también inclinación a la Teología: ve acaso en la carrera eclesiástica un posible modo de ascender más seguro que ejerciendo de puro legista. He aquí un rasgo característico en su vo-

melo Viñas y Mey (dir.), Estudios de historia social de España, Consejo Superior de Investigaciones Científicas, Madrid, 1949/60, t. II, págs. 113-151.

18 SIMANCAS, "La vida...", pág. 151b. Véanse ALCOCER, Mariano, y RIVERA, Saturnino, Historia de la Universidad de Valladolid: bio-bibliografías de juristas notables, Casa Social Católica, Valladolid, 1924, pág. 38; así como GARCÍA Y GARCÍA, Antonio, "Juristas salmantinos, siglos XVI-XVII: manuscritos e impresos", en Luis Enrique Rodríguez San Pedro-Bezares (coord.), Historia de la Universidad de Salamanca, Universidad de Salamanca, Salamanca, 2002/09, v. III.1, pág. 165.

19 MARIANA, Juan de, "Del rey y de la institución real", Obras, Manuel Rivadeneyra, Madrid, 1854, t. II, págs. 536a, 537a.

${ }^{20}$ CARO BAROJA, Las formas..., pág. 177. 
cación o profesión, al parecer"21: el Derecho como vocación medular, la Iglesia como medio instrumental. Bien entendido, naturalmente, que - de acuerdo con Ihering - "la profesión ejerce [...] una influencia decisiva, como no podía ser tampoco de otra manera. Una misma persona sería distinta si hubiese adoptado otra profesión"22, de tal suerte que una resuelta o prevalente propensión jurídica tuvo por fuerza que verse matizada por tal encauzamiento levítico. Oportunidad tendremos - de propia mano deparada- para conocer con qué entrañada modulación mixtura o combina Simancas estas dos vertientes de su inserción socio-laboral: de la lectura de sus evocadores escritos se extrae sin dificultad la bien evidente inferencia de esa predisposición intrínseca vencida hacia el campo jurídico, a una actividad de jurista que busca desplegarse por una u otra vía y siempre con escrupulosa pasión, mientras la carrera eclesiástica se revela a menudo afrontada como útil fuente de ingresos y recepción de mercedes o sinecuras, aunque esto no tiene por qué implicar hipocresía en materia de fe ni desidia en su misión apostólica, mas por otro lado también y en resumidas cuentas — nada importa ahora que mediando obediencia - nueve años de los diez al frente de la diócesis extremeña sus feligreses lo tienen ausente en Roma (o, entremedias, en Nápoles, los meses a la cabeza del virreinato), propulsor del juicio contra Carranza, jurisdiccionalmente atraído ya por el Vaticano tras su fase española de ocho años: allí, "entretuve la causa del Arzobispo de Toledo en tiempo de Pío V con los Inquisidores de España que entonces me ayudaron. Vencíla yo sólo en tiempo de Gregorio XIII con grandísima honra de España, y especialmente del Rey Católico y del Santo Oficio, con lo cual he dado por bien empleados todos mis trabajos, aunque en esta vida no se me agradeciesen"23. Entonces, desembarazado de sus responsabilidades pastorales, el horizonte ocupacional se le redujo al mundo del Derecho, aunque en una dimensión sui generis, divergente de sus previas actividades judiciales: no cabe mucha duda de que el proceso contra el primado de las Españas nació o se volvió político ${ }^{24}$, de manera que el doctor Simancas vino a desempeñar en él un papel de agente real,

${ }^{21}$ CARO BAROJA, Julio, El Señor Inquisidor y otras vidas por oficio, Alianza Editorial, Madrid, 1988, pág. 20.

22 JHERING, Rudolf von, Bromas y veras en la ciencia jurídica: ridendo dicere verum, trad. Tomás A. Banzhaf y Mariano Santiago Luque, Civitas, Madrid, 1987, pág. 275.

${ }^{23}$ Véase SIMANCAS, “La vida...”, pág. 189a.

24 Intégrense MARAÑÓN, Gregorio, "El proceso del arzobispo Carranza", Boletín de la Real Academia de la Historia 127 (1950), págs. 135-178; y ORELLA UNZUÉ, José Luis, "Causas político-culturales del proceso inquisitorial a Bartolomé de Carranza (1503-1573)”, Revista de la Inquisición 11 (2005), págs. 43-90. 
como jurista al servicio del monarca y, en el fondo, de tantos intereses creados...

Mas antes de contemplar la dicha conjunción de dedicaciones, retomemos con debido orden el hilo del expediente académico tal como su mismo titular nos lo compendia. Aunque alguno de los historiadores que se han detenido en su biografía nos lo presenta, a más de legista, también canonista - que lo fue-y teólogo ${ }^{25}$, resultaría a todas luces algo insólito que el interesado, por cuya boca no acostumbra a hablar la modestia, se contente en estas memorias con titularse tan solo doctor en Leyes cuando, de haberse visto académicamente admitido entre quienes profesan la Teología, por maravilla hubiese descuidado blasonar de ello; por el contrario, como de crédito singularmente digno de reseña, sí lo hace ante el elogio de alguien "[...] porque fuera de lo que era de Derecho, me citaba en algunas cosas notables de Teología y de Historia muy á propósito [...]”26 que en principio no parece que hubieran de presuponérsele o aguardarse de su instrucción..., pero que pudo lucrar extraoficialmente ${ }^{27}$; es más: sopésense tales cálculos a la luz de su inequívoca toma de posición en la competencia entre teólogos y juristas, que más abajo recuperaremos, a favor de estos segundos ${ }^{28}$. Y dentro de los límites del Derecho, aunque, puesto a rememorar los años universitarios, todo el énfasis lo aplica a sus progresos legispericiales hasta granjearse la borla doctoral en 1542, también es cierto que en el frontispicio de la Defensa del estatuto toledano, que publicó durante su estancia en Italia, mandó poner in utroque iure Laureato $^{29}$, por más que en su Vida y cosas notables apenas aluda, más allá de los gra-

${ }^{25}$ V. gr., HINOJOSA Y NAVEROS, Eduardo de, "Influencia que tuvieron en el Derecho público de su patria y singularmente en el Derecho penal los filósofos y teólogos españoles anteriores a nuestro siglo", Obras, Ministerio de Justicia y CSIC, Madrid, 1948, t. I, pág. 86; PEREÑA VICENTE, Luciano, La Universidad de Salamanca, forja del pensamiento político español en el siglo XVI, Universidad de Salamanca, Salamanca, 1954, pág. 70; TOMÁS Y VALIENTE, Francisco, "El pensamiento jurídico", en Miguel Artola (dir.), Enciclopedia de Historia de España, Alianza Editorial, Madrid, 1988/98, t. III, págs. 361-362; GARCÍA HERNÁN, Enrique, Políticos de la Monarquía hispánica (1469-1700): ensayo y diccionario, Fundación Mapfre Tavera, Madrid, 2002, pág. 658.

26 SIMANCAS, "La vida...", pág. 155a.

27 Así se desprende del concepto en que le pone, v. gr., SÁNCHEZ-LAURO, Sixto, "Simancas, Diego de", en Manuel Juan Peláez (ed.-coord.), Diccionario crítico de juristas españoles, portugueses y latinoamericanos, Universidad de Málaga, Zaragoza/Barcelona, 2005/08, v. II.1º págs. 547-548.

${ }_{28}$ SIMANCAS, “La vida...", págs. 160b, 162a, 169b, 174a, $181 \mathrm{~b}$.

${ }_{29}$ VELASQUEZ [de Simancas], Didaco, Defensio statuti Toletani a Sede Apostolica scepè confirmati, $m$ por his, qui bono \& incontaminato genere nati sunt, Officina Christophori Plantini, Amberes, 1575, pág. 1; ID., "La vida...”, pág. 172a. 
dos en Leyes, sino al infinito número de libros de Derechos - entrambos-y otras facultades que hubo de trabajar: sí que indica Rezabal que en parte pasó de Valladolid a Salamanca a perficionarse del derecho canonico $^{30}$, si bien, a lo que parece, se demoró bastante - hasta 1564- para colacionar en esta disciplina el superior grado académico, con lo cual tendríamos de primeras a un doctor en Leyes y licenciado en Cánones con valiosos conocimientos en las ciencias teológicas obtenidos al margen del currículo documentable: frisando el medio siglo de edad y hacia el trance de su consagración episcopal duplicaría su doctorado ya con el verde capirote y birrete de los canonistas $^{31}$, habilitado ya para exhibir su laurea en leyes y cánones en el citado volumen, que se tiraba el año 1575 en prensas antuerpienses o amberinas.

\section{PRETENSIONES Y PROFESIONES.}

Comoquiera, del estudio pinciano al salmantino y vuelta a la capital del Pisuerga,

[...] El último año leí públicamente el título De rebus dubiis, con copia de oyentes, y me opuse al colegio de Santa Cruz de Valladolid, y fuí elegido y preferido á once opositores, muchos de ellos buenos letrados. El año primero que fuí colegial comencé á leer en las escuelas [...]. El segundo año proveyeron una cátedra de Código, y casi todo el año leí dos lecciones cada día: la de mi cátedra á la mañana y la de Prima á la tarde (que por abuso de aquel tiempo se hacía así cuando el Catedrático de Prima era Oidor, y entonces lo era el doctor Mora, y estuvo ausente visitando los Adelantamientos). El año tercero me gradué de Licenciado y doctor en Leyes y dejé la cátedra, por serme impedimento en mis estudios, y por los pocos oyentes que había en Leyes, aunque yo los tenía todos; y de ahí adelante volví a pasar infinito número de libros de Derechos y otras facultades. El año de 1545 fuí llamado por consultor de la Inquisición [...]. Fuí un año Rector de la Universidad, en que se proveyeron muchas cátedras entre colegiales y otros contrarios del Colegio, y ninguno me recusó ni se arrepintió de no haberme recusado. / El año octavo de mi Colegio vacó la cátedra de Vísperas de Leyes, y contra mi voluntad me hicieron oponer á ella, [...] y siendo contra mí la Chancillería y la Villa y la Iglesia, la llevé con grandísima honra ${ }^{32}$.

${ }^{30}$ REZABAL Y UGARTE, José de, Biblioteca de los escritores que han sido individuos de los seis colegios mayores: de San Ildefonso de la Universidad de Alcalá, de Santa Cruz de la de Valladolid, de San Bartolomé, de Cuenca, San Salvador de Oviedo, y del Arzobispo de la de Salamanca, Imprenta de Sancha, Madrid, 1805, pág. 343.

31 SOBALER SECO, Catálogo..., pág. 174.

32 SIMANCAS, "La vida...", págs. 151b-152a. Repásense FLORÍA HIDALGO, María Dolores, "De rebus dubiis", Boletín de la Facultad de Derecho de la UNED 
Y es llegado este punto cuando Simancas condesciende a dispensarnos la confidencia de su auténtica vocación en el sentido de "[...] que yo siempre había deseado emplearme en servicio del Rey"; y en semejante carrera de su elección sabemos por un personaje cervantino que no hay "[...] sino estudiar y más estudiar, y tener favor y ventura; y cuando menos se piensa el hombre, se halla con una vara en la mano, o con una mitra en la cabeza" ${ }^{33}$, pero antes el estadio intermedio pasa por la azarosa condición de pretendiente, augur de los semblantes del privado ${ }^{34}$, en pos de aquellas esperanzas cortesanas del Fabio epistolar...

Después de esto hablé con el Patriarca don Fernando Niño, Presidente del Consejo Real, y le dije que yo siempre había deseado emplearme en servicio del Rey; que le suplicaba que, si en mí concurrían tantas partes cuantas en el que más de los que pretendían Audiencias, fuese servido de representarlo á Su Majestad. Respondióme que ya él tenía de mí bastante noticia; que solamente reparaba en la cátedra, que era casi incompatible con el oficio; y le dije que no había llevado la cátedra para que fuese estorbo de servir a Su Majestad, sino para público testimonio de lo que podía hacer, y que haciéndome Su Majestad merced de una Audiencia, yo vacaría luego la cátedra ${ }^{35}$.

He ahí, entonces, su genuina vocación: ni la teórica de la Jurisprudencia, esto es el enseñar, toda vez que "[...] no había llevado la cátedra [...] sino para público testimonio de lo que podía hacer"; ni la práctica abogando en el foro, pues "[...] es cierto que en toda mi vida hice escrito como Abogado, ni fué inclinado jamás mi ánimo á tal oficio" ${ }^{36}$, aunque salta a la vista que esta profesión no se limita a lo expresado, sino que abraza el consejo jurídico y, sobre todo, el pedir justicia ante los tribunales, empeño este al que Simancas sacrificó mucho tiempo y esfuerzo, sin ir más lejos, como acusador del arzobispo Carranza, mas sólida, taxativamente —así lo confiesa-, jamás percibió llamada alguna a tal oficio. En cuanto a la otra práctica de las leyes, que -en la taxonomía huartina - es el juzgar, si bien Simancas pretendió y alcanzó de primeras una oidoría, tam-

10/11 (1996), págs. 131-142; SOBALER SECO, Catálogo..., pág. 174.

33 CERVANTES, Miguel de, Don Quijote de la Mancha, ed. Juan Alcina Franch, Hijos de José Bosch, Gerona, 1977, t. II, pág. 541.

34 FERNÁNDEZ DE ANDRADA, «Epístola ..., pág. 76 (v. 54).

35 SIMANCAS, "La vida...", pág. 152a. Sobre el patriarca y presidente Niño Zapata, véanse LÓPEZ GÓMEZ, Ángela, "Los presidentes y gobernadores del Consejo Supremo de Castilla”, Hidalguía 210 (IX/X-1988), págs. 680-681; y EZQUERRA REVILLA, Ignacio, El Consejo Real de Castilla bajo Felipe II: grupos de poder y luchas faccionales, Sociedad Estatal para la Conmemoración de los Centenarios de Felipe II y Carlos V, Madrid, 2000, págs. 41-48.

36 SIMANCAS, "La vida...", pág. 152a. 
poco debió de ser esta su preferencia vocacional, sino una escala más, otro puesto de mando y manejo del poder, en servicio del Rey, dentro del sistema de designación libre (con frecuencia, gratificatorio e inadvertido tal vez de idoneidades) que impregna la administración austracista en que hubo de acoplarse ${ }^{37}$. Resulta, entonces, "[...] que yo siempre había deseado emplearme en servicio del Rey"38 y el medio que halló más expedito para ello pasaba por la magistratura. En el entramado polisinodial de la monarquía hispánica a que llegó a tener acceso, sabido es que los Consejos comprendían tanto funciones de justicia como las de gobierno, lo cual se acerca a coincidir con la tercera vía profesional que el doctor Huarte, pocos años más joven que Simancas, reservaba para los juristas: el gobernar una república ${ }^{39}$, ello si no supiéramos ser las tareas sinodiales de gobernación constitutivamente consiliarias y no decisorias ni apenas ejecutivas...

Ha instado, sí, don Diego muy encumbrada mediación en el presidente del Consejo de Castilla, mas no discurre tan fácil la cosa: primero, por las iniciales reticencias del dignatario, receloso de codicias acumulativas en el solicitante que le incitasen a retener su cátedra en propiedad ${ }^{40}$ (mas recordemos cómo nos ha contado que en el segundo año de colegial había él sustituido al catedrático de Prima, quien andaba visitando adelantamientos en su adicional calidad de magistrado de la Audiencia y Chancillería ${ }^{41} \ldots$..). De más a más, enseguida se dejan sentir mayores valimientos -en su perjuicio- cuando "[...] por negociación de privados vinieron proveídos por Oidores de Valladolid dos que nunca estuvieron en colegios, ni jamás leyeron cátedra, y me exolvieron, de que el Patriarca quedó sentido y yo más"42 (intrigas, sin duda, de esos confesos enemigos de

37 Consúltense LALINDE ABADÍA, Jesús, Los medios personales de gestión del poder público en la historia española, Instituto de Estudios Administrativos, Madrid, 1970, págs. 90-93; GARCIA MARÍN, José María, La burocracia castellana bajo los Austrias, Instituto Nacional de Administración Pública, Alcalá de Henares, 1986, págs. 32-36, 151-225.

38 SIMANCAS, "La vida...", pág. 152a.

39 HUARTE DE SAN JUAN, Examen..., págs. 466-492. Ofrece un epítome IRIARTE, El doctor..., págs. 214-215

${ }^{40}$ Póngase en relación con las consideraciones de LALINDE ABADÍA, Los medios..., págs. 139-140; o GARCÍA MARÍN, La burocracia ..., págs. 140-149.

${ }^{41}$ SIMANCAS, "La vida...", pág. 151b. En efecto, léase a ALONSO ROMERO, María Paz, El proceso penal en Castilla (siglos XIII-XVIII), Universidad de Salamanca y Diputación Provincial de Salamanca, Salamanca, 1982, pág. 112; o LAS HERAS SANTOS, José Luis de, La justicia penal de los Austrias en la Corona de Castilla, Universidad de Salamanca, Salamanca, 1994, pág. 59.

${ }^{42}$ SIMANCAS, “La vida...", pág. 152a. 
colegios que desenmascarará algunas páginas después ${ }^{43}$ ante el lector de su vida...). En recobro de la fórmula cervantina, estudiar y más estudiar lo cumplía con creces, tener favor ya se advierte conseguido: le fallaba por ahora la ventura... No obstante, año ya de 1548, sin incurrir en la corruptela dilatoria de la permanencia en el colegio simultaneada con el empleo en el tribunal ${ }^{44}$,

Desde á pocos meses volvió el Patriarca á nombrarme, y vino mi provisión hecha en Metz, y luego vaqué la cátedra y tomé posesión, y salí del Colegio, habiendo estado en él nueve años, en mucha conformidad de todos, y no se me habiendo dado cargo en alguna de las nueve visitas que en aquel tiempo se hicieron ${ }^{45}$.

Andando el tiempo, tanto como hasta 1566, tendría él mismo (flamante obispo de Ciudad Rodrigo) oportunidad de probarse en semejantes menesteres, a la par que de aprovechar su experiencia docente, comisionado por el monarca a la Universidad salmanticense con miras a que "[...] averiguase lo que allá se hacía con mal orden y por cuya culpa y qué convenía remediar en ello, porque tenía relación que no estaban aquellas escuelas como debían"46. Supondrá su reencuentro con el alma mater studiorum y la huella que el episodio deja en sus memorias - socorridamente proyectable sobre su etapa estudiantil para aprehender el genio de su talante universitario - nos pone sobre aviso de las deficiencias, así de fondo como de forma, detectadas por el visitador:

[...] y ante todas cosas escribí al Consejo que me enviasen una provisión con pena para que no dictasen los Lectores, que era una cosa perniciosa á los estudiantes, y que no se solía usar; y dije que les quitaban el ejercitar la memoria, y se la destruían, porque no encomendando las lecciones á ella, sino escribiendo lo que les dictaban los Lectores, no la cultivaban y no la acrecentaban; y también estragaban á los discípulos sus entendimientos, porque los cautivaban á lo que escribían, sin dejarles elección, y quitábanles el cuidado y diligencia, porque ya había sabido que muchos encomendaban á sus amigos ó á sus criados que les escribiesen las lecciones, y con aquello se contentaban, y sobre todo que lo que habían de leer en un mes, no esperando á que escribiesen los discípulos, no lo leían en seis meses. Yo me hallé en una lección, y vide que repetían cinco y seis veces

43 SIMANCAS, "La vida...", pág. 200a.

${ }^{44}$ SOBALER SECO, María de los Ángeles, Los colegiales de Santa Cruz: una élite de poder, Junta de Castilla y León, Salamanca, 1987, págs. 234-235.

45 SIMANCAS, "La vida...", pág. 152a. Véanse SOBALER SECO, Catálogo..., pág. 174; y, v. gr., TORREMOCHA HERNÁNDEZ, Margarita, "Visitas para el gobierno de la Universidad de Valladolid a comienzos de la Edad Moderna (15031545)", Investigaciones Históricas: Época Moderna y Contemporánea 18 (1998), págs. 34-37.

46 SIMANCAS, “La vida...", pág. $162 b$.

(C) UNED. Revista de Derecho UNED, núm. 25, 2019 
cada palabra de las que decían para que las escribiesen, porque los que eran tardos daban con el tintero muchas veces, y decía el Lector: Digo, señores; repitiéndolo hasta que [ya no] daban tinterazos. Vistas mis razones en Consejo, me enviaron una provisión, con pena de privación de cátedra, contra el que leyese y diese de aquella manera á escribir dictando. Hice juntar a todos los Catedráticos en su claustro, y mandéles notificar la provisión, lo cual sintieron tanto que no lo pudieron disimular $[\ldots]^{47}$.

Uno de ellos, verbigracia, entre otros, cada cual con su descargo y argumento, se alarga a aducirle "[...] con lágrimas que según aquello le habían de quitar la cátedra, y que había gastado en ella y en graduarse la dote de su mujer, y que quedaba destruido" 48 ... En definitiva, ante la generalizada reluctancia de la corporación,

[...] Yo le respondí que aunque en otras cosas se podía haber engañado Su Majestad, en enviarme á aquel negocio, no en una, que era en haber elegido persona que había pasado por todo aquello, y había sido catedrático y entendido y visto por experiencia lo que tocaba á los oyentes y Lectores; que lo que decía (aunque le diesen otros colores) todo pararía en excusarse de trabajo los Catedráticos y leer siempre por sus cartapacios, sin más estudiar ni recapacitar; que las cáthedras no se hicieron para dar de comer á sesenta hombres holgando, sino que les daban aquellos estipendios para utilidad de todo el reino trabajando ${ }^{49}$.

Entra además a interponerse en los abusos suntuarios, pero sin requerimiento alguno de reformas, sino contentándose con proporcionar efectiva aplicación a la normativa inobservada...

Hice mi visita $[\ldots]$ y averigüé lo que era público, que los estudiantes no guardaban estatutos ni aun pragmáticas, y que andaban vestidos tan costosos y con tanto fausto que no bastaban haciendas para sustentarlos; en sus casas tenían camas de campo, tapicerías, escritorios, mesas y sillas de nogal, y las lobas, manteos y sotanas de refino y de rajas de mucho precio, y unos bonetes ridículos, con cuatro cuernos muy grandes, y las bocas no cabían en la mitad de la cabeza; los manteos tan largos que rastraban, y otras muchas boberías á este

47 SIMANCAS, "La vida...", págs. 162b-163a. A este respecto, cotéjese con MARTÍN HERNÁNDEZ, Francisco, La formación clerical en los colegios universitarios españoles (1371-1563), Eset, Vitoria, 1961, págs. 150-152; ALEJO MONTES, Javier, La Universidad de Salamanca bajo Felipe II (1575-1598), Junta de Castilla y León, Burgos, 1998, pág. 45; o RODRÍGUEZ SAN PEDRO BEZARES, Luis Enrique, "El corpus normativo, siglos XV-XVIII”, en id. (coord.), Historia ..., v. II, pág. 121.

48 SIMANCAS, "La vida...", pág. 163a.

49 SIMANCAS, "La vida...", pág. 163a. Atiéndase a RAMÍREZ GONZÁLEZ, Clara Inés, "La polémica en torno al dictado en la Universidad de Salamanca durante el siglo XVI", en vv. aa., Aulas y saberes. VI Congreso Internacional de Historia de las Universidades Hispánicas, Universidad de Valencia, Valencia, 2003, v. II, págs. 362364. 
tono. / Escribí al Consejo que era necesario que viniese persona á ejecutar la enmienda de todas aquellas cosas, y que no era menester otras visitas ni estatutos nuevos, que hartos había muy buenos, sino que no se ejecutaban por culpa del Maestrescuela y de los Rectores, y envíeles un bonete de aquellos de media vara en largo de cuerno, con que rieron algunos mucho. / Escribíles que bien sabían que en España no suelen estudiar sino los que poco tienen, y que la principal reformación sería quitarles el abuso de los gastos. Proveyeron muy bien todo lo que les avisé, y enviaron á ejecutarlo [...]. Solamente dejaron de remediar la costa del vestido, porque no se concordaron $[\ldots]^{50}$.

De vuelta al salto o viraje laboral emprendido con favor y ventura, en Simancas encontramos el arquetipo de colegial exaltado a los puestos dirigentes de la sociedad de su época (de hecho, los colegiales de Santa Cruz copaban la Chancillería vallisoletana ${ }^{51}$ ); y algo tendrá que decir sobre esta cantera de altos servidores públicos propia del Antiguo Régimen hasta la general supresión decretada ya a últimos del siglo XVIII y a mitad del reinado de Carlos IV ${ }^{52}$, de la cual tan solo libró el San Clemente de Bolonia...: pospongamos por ahora la cuestión hasta encajarla dentro de su apología de los juristas. Dispuesto a coger en pocos días y sobre la marcha su experiencia y práctica, se incorpora, por tanto, don Diego a la Audiencia y Chan-

50 SIMANCAS, "La vida...", pág. 163b. Consúltense GIL DE ZÁRATE, Antonio, De la Instruccion Pública en España, Pentalfa, Oviedo, 1995 (facsímil de la edición del Colegio de Sordo-mudos, Madrid, 1855), t. II, págs. 264-265; GARCÍA MERCADAL, José, Estudiantes, sopistas y pícaros, Espasa-Calpe Argentina, Buenos Aires, 1954, págs. 47-49; LALINDE ABADÍA, Jesús, "La indumentaria como símbolo de la discriminación jurídico-social", en Anuario de Historia del Derecho Español 53 (1983), págs. 593-594; LA CRUZ AGUILAR, Emilio de, Lecciones de Historia de las Universidades, Civitas, Madrid, 1987, págs. 77-81; TORREMOCHA, Margarita, La vida estudiantil en el Antiguo Régimen, Alianza Editorial, Madrid, 1988, págs. 131152; CORTÉS VÁZQUEZ, Luis, La vida estudiantil en la Salamanca clásica, Universidad de Salamanca, Salamanca, 1989, págs. 52-55; PÉREZ MARTÍN, Antonio, "El Derecho y el vestido en el Antiguo Régimen", Anales de Derecho. Universidad de Murcia 16 (1998), págs. 286-288; RODRÍGUEZ SAN PEDRO BEZARES, Luis Enrique, "Vida estudiantil cotidiana en la Edad Moderna", en id. (coord.), Historia..., v. II, págs. $672-673 \ldots$

51 SOBALER SECO, Los colegiales..., pág. 232.

${ }^{52}$ Novísima recopilacion de las leyes de España, Madrid, 1805, VIII.3.9. Amplíese en ÁLVAREZ DE MORALES, Antonio, La "Ilustración» y la reforma de la Universidad en la España del siglo XVIII, Instituto de Estudios Administrativos, Madrid, 1971, págs. 135-141, 167; PESET, Mariano, y PESET, José Luis, La Universidad española (siglos XVIII y XIX): despotismo ilustrado y revolución liberal, Taurus, Madrid, 1974, págs. 107-114, 345-358; o LA CRUZ AGUILAR, Lecciones..., págs. 102104. 
cillería de Valladolid, primer tribunal segregado en el siglo XV de la corte regia ${ }^{53}$.

Un poco antes de sentar plaza en ella — según se deja dicho-, en 1545, había sido "[...] llamado por consultor de la Inquisición, y no me satisfaciendo de los libros que había en aquella materia, la estudié más de raíz y hice para mí un borrador, del cual después salieron mis Instituciones Católicas" ${ }^{4}$, las cuales, a persuasión de su concolega en el distrito granadino Diego de Covarrubias, remata en horas hurtadas durante los primeros años de su oidoría y da a la imprenta en el tercero, 1552, reimpresas con el tiempo y adiciones en Alcalá (1569) y Roma (1575) ${ }^{55}$ : sin duda, será este el título que le depare superior celebridad, pero a él van a seguir no pocos más en lo sucesivo, de mayor o menor envergadura y fortuna editorial, entre los cuales el propio Simancas resalta otros asimismo de temas inquisitoriales, como su Enquiridión ${ }^{56}$, Del padre hereje ${ }^{57}$ o, a vueltas con la limpieza de sangre, aquella Defensa del estatuto de Toledo ${ }^{58}$ ya mencionada, añadiéndoles De mayorazgos ${ }^{59}$, De ambitu, sobre la venta de oficios ${ }^{60}$, De republica ${ }^{61}$, un arte de buen gobierno que apro-

${ }^{53}$ Acúdase, v. gr., a GARCÍA DE VALDEAVELLANO, Luis, Curso de Historia de las Instituciones españolas (de los orígenes al final de la Edad Media), Revista de Occidente, Madrid, 1977, págs. 566-567.

${ }^{54}$ SIMANCAS, "La vida...", págs. 151b-152a. Véanse BERMEJO CABRERO, "Apuntamientos...", págs. 574-577; LYNN, Kimberly, "Diego de Simancas", en David Thomas et al. (eds.), Christian-Muslim relations. A bibliographical history, Brill, Leiden/Boston, 2009/17, v. VI, págs. 235-242.

55 SIMANCAS, "La vida...", págs. 152b-153a, 180a-182a; véanse además las págs. 162a, 188b-189a.

56 SIMANCAS, "La vida...", págs. 170, 180a, 181b. Véase BERMEJO CABRERO, "Apuntamientos...", pág. 578.

57 SIMANCAS, "La vida...", pág. 180a. Véase BERMEJO CABRERO, “Apuntamientos...", págs. 585-586.

58 SIMANCAS, "La vida...", pág. 172a. Ahóndese, v. gr., en SICROFF, Albert A., Los estatutos de limpieza de sangre: controversias entre los siglos XV y XVII, trad. Mauro Armiño, Taurus, Madrid, 1979, págs. 125-172, 190-194; CARO BAROJA, Julio, Los judios en la España moderna y contemporánea, Arión, Madrid, 1961, t. II, págs. 403-408; DOMÍNGUEZ ORTIZ, Los judeoconversos..., págs. 79-104, particularmente en págs. 86-88; SOBALER SECO, Los colegiales..., pág. 161; KAMEN, Henry, La Inquisición española: una revisión histórica, trad. María Morrás, Crítica, Barcelona, 1999, págs. 223-239; o BERMEJO CABRERO, “Apuntamientos...”, págs. 578-580.

59 SIMANCAS, "La vida...", pág. 162a. Véase BERMEJO CABRERO, “Apuntamientos...", págs. 572-574.

60 SIMANCAS, "La vida...", pág. 154a. Véase BERMEJO CABRERO, “Apuntamientos...”, pág. 586.

${ }_{61}$ SIMANCAS, "La vida...", págs. 154a, 160a, 181-182, 197b. Véanse PEREÑA VICENTE, La Universidad..., págs. 70-72; y BERMEJO CABRERO, "Apuntamientos...", págs. 580-584. 
vecha para vindicar el servido por letrados, De los obispos juristas ${ }^{62}$, en su respaldo frente a los de formación teologal, De la dignidad de los obispos ${ }^{63}$ o De cardenales $^{64}$, hasta el punto de jactarse porque "la fama [...] de mis letras por mis libros está muy celebrada en toda la cristiandad" 65 . Al hilo de la taxonomía del doctor Huarte, leíamos al propio Simancas sustraerse vocacionalmente al ejercicio teórico de la Jurisprudencia (la cátedra, público testimonio de su potencial...), pero aún en el Examen de aquel resta otra vía, muy cualificada, de aplicación teórica. Si en las leyes esta pertenece a la memoria y su práctica al entendimiento, en tanto que el gobernar la república queda bajo el imperio de la imaginativa, todavía cataloga el fisiólogo navarro otro acomodo para selectos ingenios con inventiva: estos "no han menester maestro que los enseñen ni les digan cómo han de filosofar; porque de una consideración que les apunta el doctor sacan ellos ciento, y sin decirles nada se les hinche la boca de ciencia y saber. [...] A estos tales está permitido que escriban libros y a otros no" 66 , como la crema de su carrera, profesión y clase, siendo el escribir libros una actividad en la que, no carente de invención, cabalmente descuella el personaje ${ }^{67}$ a lo largo de toda su azacaneada vida y a despecho del absorbente reclamo de ordinarias ocupaciones como juez civil o inquisitorial, como obispo o delegado regio ${ }^{68}$.

Con sus labores judiciales en la Chancillería vallisoletana, servidas durante diez años y medio ${ }^{69}$, más diferentes comisiones y visitas que va desempeñando, le nacen nuevas expectativas, como la regencia de Navarra que se le ofrece y que rechaza por parecerle escaso el estipendio, por más que - asegura entre otras protestas por el estilo que trufan su alegato- "[...] gracias á Dios nunca fuí codicioso ni ambicioso"; e igualmente se conduce ante una plaza de auditor en la Sacra Rota romana (la correspondiente a Castilla) o ante el cargo de

\footnotetext{
62 SIMANCAS, “La vida...”, págs. 162a, 181b. Véase BERMEJO CABRERO, "Apuntamientos...", págs. 584-585.

63 SIMANCAS, "La vida...", págs. 181b, 203b. Véase BERMEJO CABRERO, "Apuntamientos...", págs. 586-587.

${ }^{64}$ SIMANCAS, "La vida...”, pág. 181b. Véase BERMEJO CABRERO, “Apuntamientos...”, pág. 587.

${ }_{65}$ SIMANCAS, "La vida...", pág. 189a.

${ }^{66}$ HUARTE DE SAN JUAN, Examen..., págs. 343-344. Interprétese con IRIARTE, El doctor..., págs. 235-236.

${ }^{67}$ ANTONIO, Bibliotheca..., t. I, pág. 317; REZABAL Y UGARTE, Biblioteca..., págs. 344-345; CARO BAROJA, El Señor..., pág. 34; BERMEJO CABRERO, “Apuntamientos...”, págs. 571-587; SÁNCHEZ-LAURO, “Simancas...”, págs. 547-548.

68 Véase BERMEJO CABRERO, “Apuntamientos...”, pág. 571.

${ }^{69}$ SIMANCAS, "La vida...”, págs. 152a-155a. Acúdase a DOMÍNGUEZ RODRÍGUEZ, Cilia, Los oidores de las salas de lo civil de la Chancillería de Valladolid, Universidad de Valladolid, Valladolid, 1997, págs. 53, 131-132.
} 
exactor (este rehusado por escrúpulos de conciencia) del subsidio o décima que el Sumo Pontífice había concedido al monarca hispano para sufragar la guerra contra el turco ${ }^{70}$, sin hacer ahora mayor fuerza su deseo de siempre de emplearse en servicio del rey... (en este punto conviene hacer notar cómo la doctrina insiste en la naturaleza de carga que impregna todo oficio público, de manera que comporta un deber de aceptación, en conciencia y en derecho, para el súbdito seleccionado ${ }^{71}$ ). En 1558 concurre a la consulta de la Fe -el tribunal reforzado a efectos de sentenciar- en sendos procesos inquisitoriales seguidos contra el ruidoso foco luterano de Valladolid y otro criptojudaizante de Murcia ${ }^{72}$ y el año venidero se le asigna una plaza vacante en el Consejo de la Inquisición ${ }^{73}$, dentro del cual le sobrevendrán nuevas decepciones ante su preterición en el lance de cubrir la presidencia ${ }^{74}$.

Ya se ve, con todo, elevado a la cúpula polisinodial, a la coordinada urdimbre de los consejos reales que caracterizan la articulación administrativa de la Monarquía Universal, culminante así el tránsito desde la Edad Media, con el poder en manos de la nobleza propietaria, hacia una Modernidad que configura y tecnifica el Estado a lo largo de un proceso no exento de tensión ${ }^{75}$. A favor de co-

70 SIMANCAS, "La vida...", pág. 153a (esos otros descargos de codicioso o lisonjero, ibidem, págs. 189b, 193a). Intégrese mediante BERMEJO CABRERO, "Apuntamientos...”, págs. 569-570; y MARTÍNEZ MILLÁN y CARLOS MORALES (dirs.), Felipe II..., pág. 482; en cuanto a la regencia navarra, váyase a SALCEDO IZU, Joaquín José, El Consejo Real de Navarra en el siglo XVI, Universidad de Navarra, Pamplona, 1964, págs. 84-89; para el tribunal de la Rota romana en la época, a DÍAZ VARA CALDERÓN, Gabriel, Grandezas, y maravillas de la inclyta y sancta ciudad de Roma, cabeza, y compendio de el Orbe, madre de todos los fieles, y roca inexpugnable de la sancta fee catholica, Ioseph Fernández de Buendía, Madrid, 1673, págs. 212-215; y, sobre las llamadas tres gracias, comprensivas del subsidio, a CATALAN MARTÍNEZ, Elena, "El fin de un privilegio: la contribución eclesiástica a la Hacienda Real (1519-1794)", Studia Historica. Historia Moderna 16 (1997), págs. 177200.

${ }^{71}$ Compruébese en LALINDE ABADÍA, Los medios..., págs. 127-128; o GARCÍA MARÍN, La burocracia ..., págs. 96-112.

72 SIMANCAS, "La vida...", págs. 154-157, 168. Véanse TELLECHEA IDÍGORAS, "Cartas...", págs. 968-969; ALONSO BURGOS, Jesús, El luteranismo en Castilla durante el s. XVI: autos de fe de Valladolid de 21 de mayo y de 8 de octubre de 1559, Swan, San Lorenzo de El Escorial, 1983, págs. 59-117; DOMÍNGUEZ NAFRÍA, Juan Carlos, La Inquisición de Murcia en el siglo XVI: el Licenciado Cascales, Real Academia Alfonso X el Sabio, Murcia, 1991, págs. 24-59.

73 SIMANCAS, "La vida...", pág. 155b. Complétese en RODRÍGUEZ BESNÉ, José Ramón, "Perfil jurídico y social de los consejeros de la Suprema”, en Escudero (ed.), Perfiles..., págs. 567-571.

74 SIMANCAS, “La vida...", pág. 175b.

75 Recúrrase, v. gr., a GARCÍA-GALLO, Alfonso, Manual de historia del Derecho español. I. El origen y la evolución del Derecho, Artes Gráficas y Ediciones, Madrid, 
rriente (el contexto sociopolítico estructural), sigue la trayectoria de Simancas cauces prefijados, pues "a los Consejos se llegaba por el curso ordinario de la administración castellana, también del gobierno de los territorios virreinales"76 (actúa como virrey interino de Nápoles algunos meses entre 1571 y 1572, al tiempo de la más alta ocasión que vieron los siglos, en el estrecho de Lepanto ${ }^{77}$ ). Cumplido ejemplo, pues, del regular currículo exhibido por los miembros de los Consejos en la España imperial (educación universitaria al abrigo de colegio mayor más experiencia eclesiástica o jurídica), todavía completará, en efecto, el eslabonamiento sintetizado por Elliott: "designados para ocupar un cargo en una Audiencia, uno o dos de los afortunados podían esperar ser ascendidos a uno de los Consejos, y un lugar en el Consejo de Castilla constituía ya la suma de sus aspiraciones"78, porque tal va a ser, de hecho, el siguiente asalto del insaciable cordobés ${ }^{79}$. Y, ya accedido a tales eminencias, no será su descarte para el cargo de inquisidor general la mayor frustración en afligirle, sino que, sin apocamiento en sus ambiciones, llega a sentirse con capacidad y valía para aspirar a la cúspide del sistema: la presidencia de Castilla ${ }^{80}$.

[...] llegó allí la nueva de la muerte del Presidente, y luego mis amigos me avisaron con diligencia diciendo que ya aquel era lance forzoso, y que no había en España quien pudiese competir conmigo; y así en estos reinos por voz pública todos me ponían el primero, de que me pesaba, aunque sabía que aquello era despertar y enconar más los ánimos á mis émulos; pero holgaba algo de ello, no por deseo que saliese cierto, sino porque entienda el mundo en qué reputación

1982, pág. 687; o TOMÁS Y VALIENTE, Francisco, Gobierno e instituciones en la España del Antiguo Régimen, Alianza Editorial, Madrid, 1982, pág. 21.

76 GIBERT, Rafael, Historia general del Derecho español, Realigraf, Madrid, 1971, pág. 194.

77 SIMANCAS, "La vida...", págs. 173a-174a. Sirvan de contexto, RIVERO RODRÍGUEZ, Manuel, Felipe II y el gobierno de Italia, Sociedad Estatal para la Conmemoración de los Centenarios de Felipe II y Carlos V, Paracuellos de Jarama, 1998, págs. 117-118; o GALASSO, Giuseppe, En la periferia del imperio: la monarquía hispánica y el reino de Nápoles, trad. Bernardo Moreno Carrillo, Península, Barcelona, 2000, pág. 143. Con específica oportunidad, MORALEJO, Macarena, "El obispo Diego de Simancas y su papel como virrey en Nápoles", Librosdelacorte.es 4 (2012), págs. 141-153. La locución lepantina, en el "Prólogo al lector" de CERVANTES, Don Quijote..., t. II, pág. 19.

${ }^{78}$ ELLIOTT, John H., La España imperial, 1469-1716, trad. J. Marfany y M. Jiménez, RBA, Barcelona, 2006, pág. 189.

${ }^{79}$ BARRIOS, El Consejo..., págs. 332-333.

80 SIMANCAS, "La vida...", págs. 160b, 191b, 197a, 198b, 199-200, 202b. Revísese al respecto EZQUERRA REVILLA, El Consejo..., págs. 91-92, 137-141.

(C) UNED. Revista de Derecho UNED, núm. 25, 2019 
me tiene toda España, pero nunca se pudo acabar conmigo que hiciese diligencia alguna sobre ello ${ }^{81}$.

Comoquiera, en cada ocasión que Simancas nos participa su repudio para un puesto - obispado, consejo- o comisión se nos traslucen entre líneas cuando menos sus anhelos, con mucha probabilidad también celosas, inconfesas gestiones de su parte, por sí o por valedor interpuesto. En el entorno eclesiástico, desde su coadjutoría del arcedianazgo de Córdoba ${ }^{82}$ va a sentarse sucesivamente en las sillas episcopales mirobrigense (1565), pacense (1568) y zamorana $(1578)^{83}$, pero antes o entremedias se le escapan -o las desestima por inconveniencia crematística- las de Sigüenza, Palencia, Plasencia o Jaén ${ }^{84}$, incluso el arzobispado de Toledo pasa por su cabeza ${ }^{85}$, pero sobre todo le frustra no tocarse con el capelo cardenalicio que una y otra vez ve imponer a otros ${ }^{86}$, a sus ojos de menor mérito... (reprobatorio y escatimoso de cualquier paño caliente, afea Beltrán de Heredia al presuntuoso prelado el mostrarse "[...] tan hiperbólico en sus propias alabanzas como despectivo con los demás" ${ }^{87}$ ). Mientras tanto -el desagravio de la opinión viene a dar alas a su despecho-, los imparciales no dejan de estar "[...] á la mira esperando nuevas de alguna señalada merced que Su Majestad me hiciera, y toda España clamaba por mí; y así, pasado este nublado, de todas partes me dieron el pésame, como de pérdida de cosas debidas" ${ }^{88}$. En pesquisa de motivos para su postergación, encuentra y patentiza dos íntimamente conexos y otro más concomitante: el primero, en cuanto referido al manadero de varas y mitras, consiste en el desvío regio, aunque sus quejas de ingratitud se apresura a excusar que "[...] no se deben entender por el Rey, sino por algunos Ministros; que Su Majestad me ha hecho mucha merced y creo que me hiciera más, [...] si no le escribieran ó mal informaran los que no sé por qué me quieren mal; pero yo se lo perdono" ${ }^{89}$, de tal manera que ahí se

${ }^{81}$ SIMANCAS, “La vida...”, pág. 197a. El fallecido era -1577- su buen amigo Diego de Covarrubias (véase LÓPEZ GÓMEZ, "Los presidentes...”, págs. 682-683).

82 SIMANCAS, “La vida...", pág. 153b.

83 SIMANCAS, "La vida...", págs. 159-160, 168a, 198a. Verifíquese en GUITARTE IZQUIERDO, Vidal, Episcopologio español (1500-1699): españoles obispos en España, América, Filipinas y otros países, Instituto Español de Historia Eclesiástica, Roma, 1994, pág. 76.

${ }^{84}$ SIMANCAS, "La vida...", págs. 158b, 191b-193a, 198a, 203a.

${ }^{85}$ SIMANCAS, "La vida...", págs. 164b, 194a.

86 SIMANCAS, "La vida...", págs. 170b-171a, 184b, 194, 201a.

87 BELTRÁN DE HEREDIA, Vicente, Domingo de Soto: estudio biográfico documentado, Instituto de Cultura Hispánica, Salamanca, 1960, pág. 138.

${ }^{88}$ SIMANCAS, “La vida...", pág. 193.

89 SIMANCAS, "La vida...", pág. 194b. Léase esto a la luz de CARO BAROJA, El Señor..., pág. 36; GARCÍA MARÎN, José María, "La burocracia de Carlos V”, en 
nos procura la otra clave que opera en intrínseca correspondencia con aquella desafección: las insidias de los que moteja mis émulos...

[...] Yo respondí que no había faltado entre algunos ministros del Rey conocimiento, sino sobrada malicia, y que yo entendía que los que habían querido escurecer mis méritos y servicios lo habían hecho con malos medios y peores fines; los unos por envidia y propios intereses, y los otros por miedo que tuvieron á la verdad y fidelidad sin interese mío, con las cuales cosas siempre he servido [...], el cual miedo no pudo nacer de mi condición (que siempre fué blanda y sin perjuicio de tercero), sino del vermículo de su conciencia, que les debe de remorder si no han tratado fielmente sus oficios, lo cual se entiende bien claro de algunos dellos, que habiendo entrado muy pobres á servir al Rey dentro de pocos años están riquísimos. / Otros me han sido enemigos secretos porque habiendo ellos servido muy mal no han sido castigados, antes han recibido premios, y á los tales pésales que otros sirvan bien y que los buenos servicios sean galardonados. Otros porque defendí el estatuto de Toledo me tienen odio; y otros de miedo que si yo quedaba en la corte y el Rey me conociese y tratase, ellos quedarían muy desacreditados y quizá perderían la gracia del Rey que indignamente habían ganado ${ }^{90}$.

En convergencia con esas asechanzas rivales nos señala Simancas la privación del oportuno contrapeso, debida a una supuesta impericia o incuria suya en las mañas del hacer antesala, toda vez "[...] que habiendo sido siempre en Salamanca de los que más madrugaban, y lo mismo en el Colegio y Chancillería, y nunca habiendo podido dormirme oyendo lección, ni sermón, ni caminando, ni siendo jamás notado de soñoliento, [...] me dormía en negociar"91 en pos de la prebenda o sinecura; antes bien, asevera el memoriógrafo "[...] que yo ni con el Papa, ni con sus privados, ni con el Rey, ni con los suyos usaba de medios para capelo ni para alcanzar otra merced"92. Tales negociaciones y el consectario inficionamiento de la administración constituyen uno de sus más constantes desasosiegos, como damnificado que se siente una vez y otra por una mala praxis a la hora de dotarse Estado e Iglesia de medios personales. Por supuesto, no todas las proteicas variantes de nepotismo, simonía, arribismo, endogamia burócrata, etcétera, le afectan subjetivamente ni le preocupan por igual: sí distingue entre ellas la problemática de la com-

Francisco Sánchez-Montes González y Juan Luis Castellano (coords.), Carlos V, europeísmo y universalidad: la organización del poder, Sociedad Estatal para la Conmemoración de los Centenarios de Felipe II y Carlos V, Madrid, 2001, v. II, pág. 286; y ESCUDERO, José Antonio, Felipe II: el Rey en el despacho, Editorial Complutense, Madrid, 2002, págs. 535-540.

90 SIMANCAS, "La vida...", págs. 202b-203a.

91 SIMANCAS, "La vida...”, pág. 196.

92 SIMANCAS, "La vida...", pág. $184 \mathrm{~b}$. 
praventa de oficios públicos, que - como sabemos- le moviera a escribir De ambitu, "vistos los desórdenes que había en vender los oficios de la Chancillería, so color de renunciaciones, y el daño que desto venía á la República, y la fraude que se hace á las leyes, que justísimamente en esto disponen" ${ }^{93}$, ante lo cual se resuelve a poner orden en los argumentos recabables y esgrimirlos para su condena, conforme era de aguardar en quien no disponía de otro bagaje que las propias prendas personales y curriculares, en quien además estaba seguro de su excelente proyección dentro de un sistema de puro meritoriaje ajeno a venalidades y favoritismos.

Incluso sin incurrir en semejante fraude estructural, aún le inquieta otra estridencia en el modus operandi aceptado para la provisión de cargos, puesta su atención "[...] en las elecciones de oficio con el mucho artificio que en ellas se usaba, mas que el engaño sería menor si se entendiese [...]" por parte de la instancia competente para la designación "[...] que ternía en poco al que le quisiese engañar, y si no creyese á uno sólo, sino á muchos contestes, y que no se infiriesen, porque el que venía á negociar por alguna necesidad le había de hablar y encubrir sus faltas" ${ }^{94}$, lacra esta que coincide exactamente con la justificativa de los querellosos desengaños antevistos en torno al suceso de sus esperanzas sobre la particular hoja de servicios que iba pergeñando; así que compromete su péñola "[...] para que sirva de aviso á los Reyes y Papas que no crean sin mucho fundamento en materia tan grave á los medianeros que les quisieren persuadir que provean [...] en personas de que no tengan muy entera relación del estado en que están aquellos á quien quieren proveer" 95 . En un ir a más, se alarga aún a encarecer, respirando por la herida, "[...] que cuanto erraban los Príncipes en las elecciones, engañados por falsas relaciones, no era de maravillar, porque al fin se habían de fiar de algunos; mas cuando se engañaban á sí mesmos contra lo que veían por vista de ojos, que no sabía qué excusa podían tener con Dios ni con las gentes" 96 , siendo tan diáfano que la clave

93 SIMANCAS, "La vida...", pág. 153b. Puede contextualizarse en FRAGA IRIBARNE, Manuel, y BENEYTO PÉREZ, Juan, "La enajenación de oficios públicos en su perspectiva histórica y sociológica”, en vv. aa., Centenario de la Ley del Notariado. Sección primera: estudios históricos, Junta de Decanos de los Colegios Notariales de España, Madrid, 1964/65, v. I, págs. 399-465; o en TOMÁS Y VALIENTE, Francisco, "Opiniones de algunos juristas clásicos españoles sobre la venta de oficios públicos", en vv. aa., Filosofía y Derecho: estudios en honor del profesor José Corts Grau, Universidad de Valencia, Valencia, 1977, págs. 627-649.

94 SIMANCAS, "La vida...", pág. 157b.

95 SIMANCAS, "La vida...", pág. 203a. Sobre el modo de proceder del reputado Rey Prudente, ESCUDERO, Felipe II..., págs. 535-540, 582-586.

96 SIMANCAS, "La vida...", pág. 171a. 
del acierto radica en que el soberano o el comisionado por cuenta suya y de la administración no pretenda "[...] el provecho de los que nombrase, sino su servicio y contentamiento" 97 propio o sea el interés público.

Sin abandonar el dominio de la selección de personal para gobierno de la monarquía, tercia Simancas en otra controversia que traspasaría todo el Antiguo Régimen (aún a más de un par de siglos hasta su conclusión dictada por el ministro Urquijo en 1798) cuando reprueba la que llama "[...] invención de confesos, enemigos de colegios, y es bordón de herejes condenar las cosas buenas porque haya en los que administran algunos abusos", dando así por cosa buena - becado que fuera él en el vallisoletano de Santa Cruz- la preponderancia del colegialismo ${ }^{98}$, entiéndase de los colegios mayores en orden a abastecer los cuadros directivos de los poderes civil y clerical $^{99}$.

Y porque los que desean que los colegios se pierdan ó que dejen entrar hombres malvados en ellos han inventado una fábula en tiempos pasados, y ahora vuelven á ella diciendo que no deben salir los colegiales desde el colegio á oficios mayores sin que primero pasen por oficios menos principales, digo que es invención falsa y mala, porque para oficios perpetuos no es menester experiencia de otros menores, sino muchas letras y buen seso, y la experiencia y práctica de las Chancillerías allí se aprende en pocos días, y la de los oficios temporales no aprovecha para esto, antes estorba, y en ellos se olvidan las letras, porque no se puede estudiar con aquellas ocupaciones, y menos en los mesones andando en las residencias; y desto hay notoriedad y evidencia, y experiencias cotidianas; es verdad que no todos los colegiales son grandes letrados, ni de mucho seso, pero por aquéllos no han de perder los otros ${ }^{100}$.

97 SIMANCAS, “La vida...”, pág. 161a.

98 SOBALER SECO, Los colegiales..., pág. 225.

99 Recórranse los textos compilados por AGUILAR PIÑAL, Francisco, Los comienzos de la crisis universitaria en España, Magisterio Español, Madrid, 1967, págs. 23-27, 99-115; con la vista puesta, v. gr., en ÁLVAREZ DE MORALES, La «Ilustración»..., pág. 32; ID., Estudios de Historia de la Universidad española, Pegaso, Madrid, 1993, págs. 65-67; o CARABIAS TORRES, Ana María, Colegios mayores: centros de poder (los colegios mayores de Salamanca durante el siglo XVI), Universidad de Salamanca y Diputación Provincial de Salamanca, Salamanca, 1986, v. II, págs. 913-933; pero, sobre todo, por extenso, en KAGAN, Richard L., Universidad y sociedad en la España moderna, trad. Luis Toharia, Tecnos, Madrid, 1981, págs. 130-201; y con singularidad en SOBALER SECO, Los colegiales ..., págs. 225-241.

100 SIMANCAS, "La vida...", pág. 200. Profundícese en GARCÍA MARÍN, José María, "El dilema ciencia-experiencia en la selección del oficial público en la España de los Austrias", Revista de Administración Pública 103 (I/IV-1984), págs. 185207.

(C) UNED. Revista de Derecho UNED, núm. 25, 2019 


\section{DEFENSA DE LOS JURISTAS: IURISPERITOS ESSE UTILISSIMOS.}

No desdeña Simancas oportunidad de proclamarse legisperito ${ }^{101}$ ni —con el asimismo jurisconsulto Gregorio XIII, boloñés, gobernando a la sazón la barca de San Pedro ${ }^{102}$ - de volver por los fueros y la dignidad de su grupo con la redacción de una breve defensa reivindicativa. Mas su obra toda exhala semejante espíritu: si, en general, "el inquisidor no sale tanto del campo de la pura Teología como del estudio del Derecho canónico: es jurista, hombre de leyes, antes que teólogo especulativo" - elucida Caro Baroja-, en concreto no otra cosa se deja predicar de Simancas al trasluz de su escritura: "en ella se ve de cuerpo entero lo que puede ser un jurista en frío, razonando sobre cánones, penas y 'delitos de fe', sin el menor aliento de espiritualidad trascendente" ${ }^{103}$. De la ejecutoria en tales cometidos que al final de sus días dejara no hay más que decir sino confrontar los diversos pareceres emitidos sobre su figura, desde los encarecimientos cosechados entre los más conspicuos colegas coetáneos, cuales Diego de Covarrubias, quien le concede el timbre de viri omnium consensu doctissimi ${ }^{104}$, Sarmiento de Mendoza, compañero en la Chancillería, el de divini et humani iuris peritissimus, variaeque lectionis refertissimus thesaurus ${ }^{105}$, Luis de Molina el de Iurisconsultus clarissimus ${ }^{106}$ o García de Saavedra, fiscal en la misma audiencia

101 Así lo subraya BERMEJO CABRERO, “Apuntamientos...”, pág. 584.

102 Repásese SIMANCAS, “La vida...", pág. 174a.

103 CARO BAROJA, Julio, Vidas mágicas e Inquisición, Taurus, Madrid, 1967, v. I, pág. 21.

104 COVARRUVIAS DE LEYVA, Didaco, "Variarum resolutionum", Opera omnia, Cramer, Perachon \& Cramer Filii, Ginebra, 1723, t. II, pág. 192b. Véanse ANTONIO, Bibliotheca..., t. I, págs. 276b-279b; VALES FAILDE, Javier, "Diego de Covarrubias y Leiva", en vv. aa., Jurisconsultos españoles: biografías de los ex-Presidentes de la Academia y de los jurisconsultos anteriores al siglo XX inscritos en sus lápidas, Real Academia de Jurisprudencia y Legislación, Madrid, 1911/1914, t. I, págs. 43-50; GIBERT, Rafael, Ciencia jurídica española, Francisco Román, Granada, 1982, pág. 13; ALVARADO, Javier, "Diego de Covarrubias y Leyva”, en Rafael Domingo (ed.), Juristas universales, Marcial Pons, Madrid/Barcelona, 2000, v. II, págs. 202-206; ID., “Covarrubias Leyva, Diego de”, en Peláez (ed.-coord.), Diccionario..., v. I, págs. 255257; EZQUERRA REVILLA, El Consejo..., págs. 113-139.

105 SARMIENTO, Francisco, Selectarum interpretationum, Felipe Junta, Burgos, 1573, f. 3v.b. Véanse ANTONIO, Bibliotheca..., t. I, págs. 476b-477b; PELÁEZ, Manuel Juan, "Sarmiento de Mendoza, Francisco", en id. (ed.-coord.), Diccionario..., v. II. $1^{\circ}$, pág. 518.

106 MOLINA, Ludovico de, De Hispanorum primogeniorum origine, ac natura, Pedro Landry \& Ambrosio du Port, Medina del Campo, 1588, Prefatio, $n^{\circ} 25$. Véanse ANTONIO, Bibliotheca..., t. II, págs. 52b-53a; HERNÁNDEZ PINTEÑO, José, "Luis de Molina”, en vv. aa., Jurisconsultos..., t. II, págs. 21-23; GIBERT, Ciencia..., pág. 17. 
vallisoletana, el de ingenii perspicuitate et iudicii optimi ${ }^{107} . .$. , hasta el dictamen de Nicolás Antonio - es decir de una posteridad ya del siglo contiguo-, quien le llama virus, praeter exactam juris cognitionem, politices aeque gnarum, ecclesiasticae historiaeque, ac multiplici eruditione perornatum, gravique ac emendato dicendi genere ${ }^{108}$.

Diego de Simancas se siente jurista por encima de todo ${ }^{109}$ y no deja de salir en defensa de la idoneidad de este colectivo para ejercer labores rectoras tanto en la esfera seglar como en la eclesiástica, por ejemplo, consignando con irritación en cuanto a aquel primer ámbito, cómo "[...] entre idiotas y enemigos de justicia se levantó una voz falsa contra los letrados, diciendo que atados á sus leyes no sabían gobernar", en donde al punto halló ocasión de tomar la pluma - reseñado queda- "[...] y escribir el libro De República, que después ha crecido mucho, y no lo proseguí entonces porque la falsa opinión duró poco [...]"110, de momento, pues la contumacia de tal parecer le hará llevar adelante su composición hasta darlo a la imprenta en Valladolid y 1565, con tres ulteriores reimpresiones en vida suya (compuestas en tórculos de Venecia, Amberes y Salamanca) ${ }^{111}$, lo que viene a atestiguar mejor que otro indicio en cuánta medida llegó a hacerse recurrente este prejuicio que actuaba como reacción ante la progresiva —su mayor pujanza, desde el siglo XV de los Reyes Católicos- toma funcionarial del poder, con acaparamiento de los expertos del Derecho en líneas generales y por largo tiempo ${ }^{112}$, tanto que para concretos sectores de la función pública sin especialidad jurídica no puede, de facto, darse la fase por superada. Merced a esta política $-\mathrm{y}$ de conformidad con Kagan-, un vínculo formal y permanente se trababa entre las superiores instituciones docentes, con su epicentro colegial, y las administrativo-gubernamentales, como partes correlativas que venían a ser en el monopolístico suministro de letrados para el incipiente fun-

107 GARSIA GALLECO [García de Saabedra], Ioannis, Tractatus de expensis et meliorationibus omnibus causarum patronis, Officina Nutiana, Amberes, 1586, pág. 7b. Véase ANTONIO, Bibliotheca..., t. I, pág. 699.

108 ANTONIO, Bibliotheca..., t. I, pág. 317a.

109 CARO BAROJA, El Señor..., pág. 21.

110 SIMANCAS, "La vida...", pág. 154a. Toca este punto EZQUERRA REVILLA, El Consejo..., pág. 65.

111 Así lo asienta SERRANO Y SANZ, en nota a Simancas, "La vida...", pág. 160a; ratificado por BERMEJO CABRERO, “Apuntamientos...”, pág. 581.

112 Acúdase al malogrado - para bien- jurista AZORÍN, "El personal político", Ni sí, ni no, Destino, Barcelona, 1965, págs. 169-171; también, a LALINDE ABADÍA, Jesús, Iniciación histórica al Derecho español, Ariel, Barcelona, 1978, pág. 490.

(C) UNED. Revista de Derecho UNED, núm. 25, 2019 
cionariado ${ }^{113}$ - hombres de expediente y balduque los llama Caro Baroja ${ }^{114}$ - , lo cual está pidiendo además su enlace con lo que arriba se apuntó sobre la promoción desde las cátedras al cursus honorum administrativo, aparte el contingente de egresados con su habilitante título. Acerca del fundamento referencial de este proceso, a priori de una coyuntura histórica marcada por el celo en delinear un estilo centralizado de gobernación y justicia, basta reparar en la mucha parte que la acción regulativa lleva en las cosas de gobierno para conocer la relevancia que puede alcanzar en ellas la disponibilidad de un bagaje jurídico ${ }^{115}$. En consecuencia, no apareciendo la condición de jurista como ingénitamente necesaria, siempre habrá de pedir el puesto de mando contar con el consejo de quien sí lo sea ${ }^{116}$ (piénsese en la muy ilustrativa figura del corregidor, que admitía ese dualismo taxonómico, de letras o de capa y espada -en línea con la terminología que hizo fortuna-, exclusivamente justificado por las condiciones de acceso al cargo, mas sin afectar al elenco competencial,

113 KAGAN, Universidad..., pág. 114. Atiéndase, además, a GARCÍA MARÍN, José María, El oficio público en Castilla durante la Baja Edad Media, Universidad de Sevilla, Sevilla, 1974, págs. 121-122, 218-224; PESET, José Luis, "Las críticas a la universidad de Juan Huarte de San Juan", en Luis Enrique Rodríguez-San Pedro Bezares (ed.), Las universidades hispánicas: de la monarquía de los Austrias al centralismo liberal, Junta de Castilla y León y Universidad de Salamanca, Salamanca, 2000, t. I, págs. 387-395; RODRÍGUEZ-SAN PEDRO BEZARES, Luis Enrique, y POLO RODRÍGUEZ, Juan Luis, "Los juristas: matrículas, grados y promoción académica en la Universidad de Salamanca, siglos XVI-XVII", en De Dios et al. (coords.), El Derecho..., pág. 210; así como a DIOS, Salustiano de, "La tarea de los juristas en la época de los Reyes Católicos", en Luis Enrique Rodríguez-San Pedro Bezares y Juan Luis Polo Rodríguez (eds.), Saberes y disciplinas en las universidades hispánicas, Universidad de Salamanca, Salamanca, 2005, págs. 33-40.

114 CARO BAROJA, Julio, Los moriscos del reino de Granada, (ensayo de historia social), Instituto de Estudios Políticos, Madrid, 1957, pág. 24.

${ }^{115}$ Es idea de general aceptación que está, v. gr., ya en autoridad tal como CICERÓN, Marco Tulio, Sobre la república, trad. Álvaro d’Ors, Gredos, Madrid, 1984, pág. 154.

${ }_{116}$ Léense entre las muchas y substanciosas consideraciones que CERVANTES, Don Quijote..., t. II, pág. 278, pone en labios del ingenioso hidalgo con ocasión del gobierno insular de Sancho las relativas a "[...] los gobernadores caballeros y no letrados, que sentencian con asesor". Ya encontramos asesores o consejeros, por ejemplo, en Las siete Partidas del sabio Rey don Alonso el Nono, ed. Gregorio López, Andrea de Portonaris, Salamanca, 1555, II.9.5, adscritos a la casa del rey, o, para los adelantados, ibidem, II.9.22. Amplíese esto, por lo demás, v. gr., en FURIÓ CERIOL, Fadrique, "El Concejo y Consejeros del Príncipe» y otras obras, ed. Diego Sevilla Andrés, Institución Alfonso el Magnánimo, Valencia, 1952, págs. 115-116, 125, 127 y 132; en RAMÍREZ DE PRADO, Lorenzo, Consejo y consejero de príncipes, ed. Juan Beneyto, Instituto de Estudios Políticos, Madrid, 1958, págs. 163-166, traduciendo y anotando los Aforismos políticos de Iván de Chokier; o en ZEVALLOS, Geronymo de, Arte Real para el buen govierno de los Reyes, y Principes, y de sus vassallos, ed. Salustiano de Dios, Centro de Estudios Políticos y Constitucionales, Madrid, 2003 (edición facsímil de la príncipe de Toledo, 1623), fs. 49-50, 59b. 
que se mantenía uno y cuyo ejercicio en el segundo caso requirió de necesidad el auxilio de juristas subalternos, llamáranse tenientes letrados o alcaldes mayores ${ }^{117}$ ). Se impone así la necesidad o conveniencia de los asistentes jurídicos, cuajando el instituto de la lugartenencia ${ }^{118}$, si bien, ello subscrito y en última instancia, mucho mejor parecerá no precisar de asesoramiento o auxilio técnico alguno por poseer su titular los conocimientos convenientes ${ }^{119}$, yendo - en feliz imagen de Salcedo de Aguirre - "[...] siempre sobre los estribos como señor de lo que dice y hace, y como sobrestante de los otros letrados"120: así precisamente sentía el polemista Simancas.

Por lo concerniente a la órbita eclesial, indignado ante la proliferante crítica "[...] á los juristas que aceptan obispados y á quien se los da" e, identificando al dominico Domingo de Soto y al franciscano Miguel de Medina121, "visto que algunos [...] teólogos ambiciosos y de menor cuantía seguían esta mala doctrina" ${ }^{122}$, apareja su breve defensa de los juristas, según nos la describe, cuyo título exacto es De Episcopis iuris peritis - que el abate Lampillas pondera como de mucha erudición $n^{123}$-, incorporando el opúsculo a las Instituciones católicas en tiempo de reeditarlas:

Solos unos pocos teólogos de menor cuantía que con dos sermones decorados de un cartapacio se desvanecen y piensan y dicen que con aquello poco merecen todas las prelacías del mundo, estos tales se agraviaron tanto de aquellas palabras que añadí en defensa de los

117 CASTILlO DE BOVADILlA, Jerónimo, Política para Corregidores, y Señores de vassallos, en tiempo de paz, y de guerra, Iuan Bautista Verdussen, Amberes, 1704, t. I, págs. 71 (I.6.6), 73-74 (I.6.14-16). Consúltense, v. gr., LALINDE ABADÍA, Iniciación..., pág. 490; o CANO VALERO, José, "La enseñanza en la Meseta meridional: formación práctica de los letrados castellanos (siglos XVI y XVII)", en Javier Alvarado (ed.), Historia de la literatura jurídica en la España del Antiguo Régimen, Marcial Pons, Madrid/Barcelona, 2000, v. I, pág. 416.

118 GARCÍA MARÍN, El oficio..., pág. 122.

119 Vuélvase sobre Las siete Partidas, II.2.16.

120 SALCEDO DE AGUIRRE, Gaspar, "Letra para un estudiante" [ed. Esteban Torre Serrano], Archivo Hispalense 66.202 (1983), pág. 85.

121 SOTO, Domingo de, De la justicia y del derecho, trad. Marcelino González Ordóñez, Instituto de Estudios Políticos, Madrid, 1967/68, t. II, págs. 258b-259b (III.6.2); MEDINA, Michaëlle, Christianae paraenesis, sive de recta in Deum fide, Iordani Zileti, Venecia, 1564, fs. 114v-118r (III.13), principalmente. Sobre las respectivas posiciones en esta polémica, léase a BELTRÁN DE HEREDIA, Domingo..., pág. 138.

122 SIMANCAS, "La vida...", pág. 162a.

123 LAMPILLAS, Xavier, Ensayo histórico-apologético de la literatura española contra las opiniones preocupadas de algunos escritores modernos italianos, trad. Josefa Amar y Borbón, Imprenta de Don Pedro Marín, Madrid, 1789, t. IV, pág. 135. Véanse REZABAL Y UGARTE, Biblioteca ..., pág. 345; HINOJOSA Y NAVEROS, "Influencia...”, pág. 79; BERMEJO CABRERO, “Apuntamientos...”, págs. 584-585.

(C) UNED. Revista de Derecho UNED, núm. 25, 2019 
juristas (ó por mejor decir en defensa de la verdad católica), que hicieron rumor que yo decía allí mal de la Teología y de los teólogos, y uno que había sacado todas sus obras de herejes añadió que yo afirmaba que no era oficio de Obispos predicar. / Desque fui avisado dello [...], y porque como en España no pudo chupar libros de herejes parece que quiso calumniar mi libro católico y mostrarse ingenioso en obra ajena, fué necesario que yo hiciese la obra De los Obispos juristas $[\ldots]^{124}$.

$\mathrm{Y}$, en efecto, se pronuncia allí sin reservas ni titubeos, arguyendo que episcopos jurisperitos esse vtilissimos, sobre todo para las grandes diócesis, con innumerables negocios que atender ${ }^{125} \ldots$; hacia las postrimerías de la centuria, Castillo de Bovadilla, en su celebrada Política para corregidores, dictaminaba, sobre doctrina del Hostiense y del Abad Panormitano, "[...] que para la paz se debe preferir el Jurista, y para la guerra el Theologo", entendido que "llámo aquí guerra la sedicion, y pertubacion de los Hereges, y llámo paz, quando el Prelado rige obejas Christianas" ${ }^{126}$, con lo cual viene a corroborar en esencia las bondades de los saberes jurídicos de cara a apacentar la grey en condiciones normales. Tampoco obvia Simancas la confrontación entre juzgadores juristas y teólogos en el seno de la magistratura inquisitorial a cuenta de la respectiva idoneidad ${ }^{127}$, un debate en el que vuelve a terciar en defensa de los primeros, con autoridad que invocan, verbigracia, Diana y Montes de Porres: "y para el processo, y examen, podran valerse de peritos consultores"128 en lo teológico. Y así, con estas y otras querellas, va abocando don Diego al punto final: "[...] no teniendo otras ocupaciones, he escrito estos comentarios con toda verdad hasta hoy 26 de noviembre de 1577"129, aunque luego de esta datación todavía dilata estos comentarios un año más ${ }^{130}$, hasta sus sesenta y cinco de edad y a falta del postrero lustro para su tránsito de este mundo al otro.

${ }^{124}$ SIMANCAS, "La vida...", pág. 181 b.

125 SIMANCAS, Jacobo de, De catholicis institutionibus, liber, ad praecavendas et extirpandas haereses admodum necessarius, Andrés de Angulo, Alcalá de Henares, 1569 , f. 114 r (c. XXV).

126 CASTILLO DE BOVADILLA, Política..., t. I, pág. 85b.

127 SIMANCAS, "La vida...", págs. 169b, 174a. Léase a CARO BAROJA, El Señor..., págs. 20-21; ID., Las formas..., págs. 178-179.

128 MONTES DE PORRES, Antonio, Suma de D. Antonio Diana. Recopilado en romance, Melchor Sánchez, Madrid, 1657, pág. 410b.

129 SIMANCAS, "La vida...", pág. 197a.

130 SIMANCAS, "La vida...", págs. 197b-205a. 


\section{RECAPITULACIÓN.}

Catedrático, magistrado, consejero del rey y obispo, deja Simancas en primera persona la impresión de haberse percibido y haber actuado con preferencia como jurista. Hacia el exterior también, sobre la arena de la barojiana lucha por la vida y a impulso de congénito temperamento, si no era ya bastante poderoso o decisivo el medio ambiente, dio en conducirse como el sulquivagante pretensor de Quevedo ${ }^{131}$... A fin de cuentas, su trayectoria — vida y cosas notables - se corresponde o cabe identificarla con cierto paradigma de jurista propio de la Alta Edad Moderna, aquel que conjuga un ministerio eclesiástico con el desempeño de altos puestos en la vida pública civil: la cátedra universitaria y el canonicato, la oidoría y la coadjutoría archidiaconal, el Consejo Real y el báculo diocesano...

Colocado ante el friso que de esas su vida y cosas notables ofrece Simancas, no ha pasado por alto Caro Baroja la evidencia de una carrera no tan brillante como prometía, amargada al fin por ambiciones no satisfechas ${ }^{132}$. Entre líneas ha probado a leer en el corazón del escritor y lo ha descubierto ambicioso sin satisfacer, asimismo envidioso de los honores y cargos públicos concedidos a otros, también soberbio en cuanto a los propios méritos ${ }^{133}$ : "por delante le pasaron los arzobispados y los capelos, la presidencia de Castilla, el cargo de gran inquisidor. Cuando estaba confiado en que llegaba la hora de la gran recompensa, de la recompensa suprema, las esperanzas se desvanecían. El final de su autobiografía no es más que una larga enumeración de desengaños, un cúmulo de reflexiones amargas que quieren ser cristianas y que no lo resultan". Diego de Simancas no se contentó jamás con su suerte; acaso, a la vista de cómo discurrieron para él los trabajos y los días, no le habría venido nada mal la admonición del inspirado mílite sevillano con cuya Epístola moral se abrían los presentes párrafos: "cese el ansia y la sed de los oficios"134. Sic transit gloria mundi...

131 QUEVEDO, Francisco de, Poesía original completa, ed. José Manuel Blecua, Planeta, Barcelona, 1981, pág. 1176 (nº 836, v. 1).

132 CARO BAROJA, Las formas..., pág. 178. Incide en lo mismo BERMEJO CABRERO, “Apuntamientos...”, pág. 569.

133 CARO BAROJA, El Señor..., pág. 34.

134 FERNÁNDEZ DE ANDRADA, «Epístola..., pág. 76 (v. 55). 